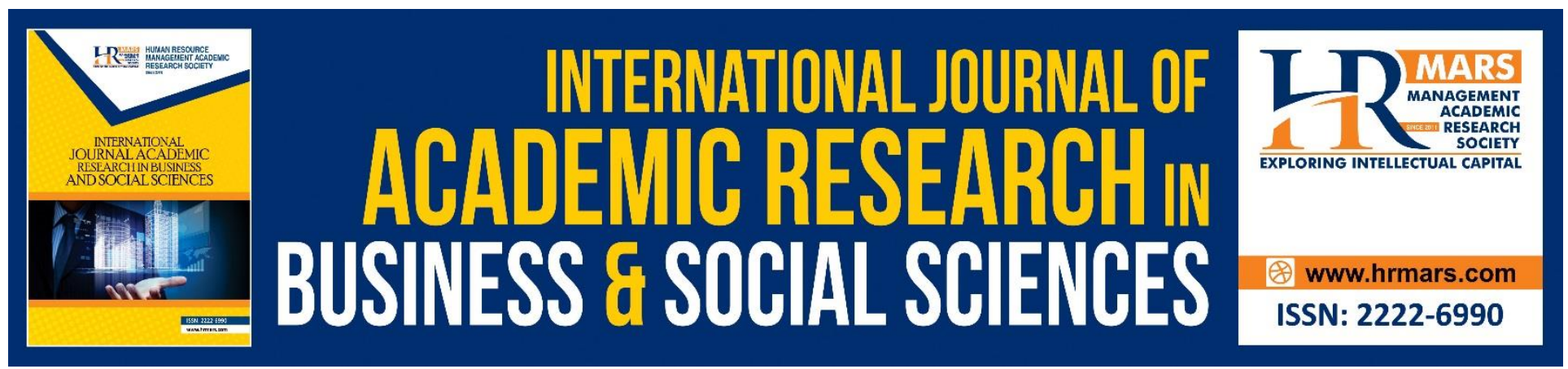

\title{
Digital Innovation: Competitive Strategy for College Startups in Nigerian Campuses
}

Jude Kenechi, Onyima

Purity, Ndubuisi

To Link this Article: http://dx.doi.org/10.6007/IJARBSS/v8-i11/4980

DOI: $10.6007 /$ IJARBSS/v8-i11/4980

Received: 21 Oct 2018, Revised: 17 Nov 2018, Accepted: 19 Nov 2018

Published Online: 16 Dec 2018

In-Text Citation: (Jude Kenechi \& Purity, 2018)

To Cite this Article: Jude Kenechi, O., \& Purity, N. (2018). Digital Innovation: Competitive Strategy for College Startups in Nigerian Campuses. International Journal of Academic Research in Business and Social Sciences, 8(11), 1007-1021.

\section{Copyright: (c) 2018 The Author(s)}

Published by Human Resource Management Academic Research Society (www.hrmars.com)

This article is published under the Creative Commons Attribution (CC BY 4.0) license. Anyone may reproduce, distribute, translate and create derivative works of this article (for both commercial and non-commercial purposes), subject to full attribution to the original publication and authors. The full terms of this license may be seen

at: http://creativecommons.org/licences/by/4.0/legalcode

\section{Vol. 8, No. 11, 2018, Pg. 1007 - 1021}

Full Terms \& Conditions of access and use can be found at http://hrmars.com/index.php/pages/detail/publication-ethics 


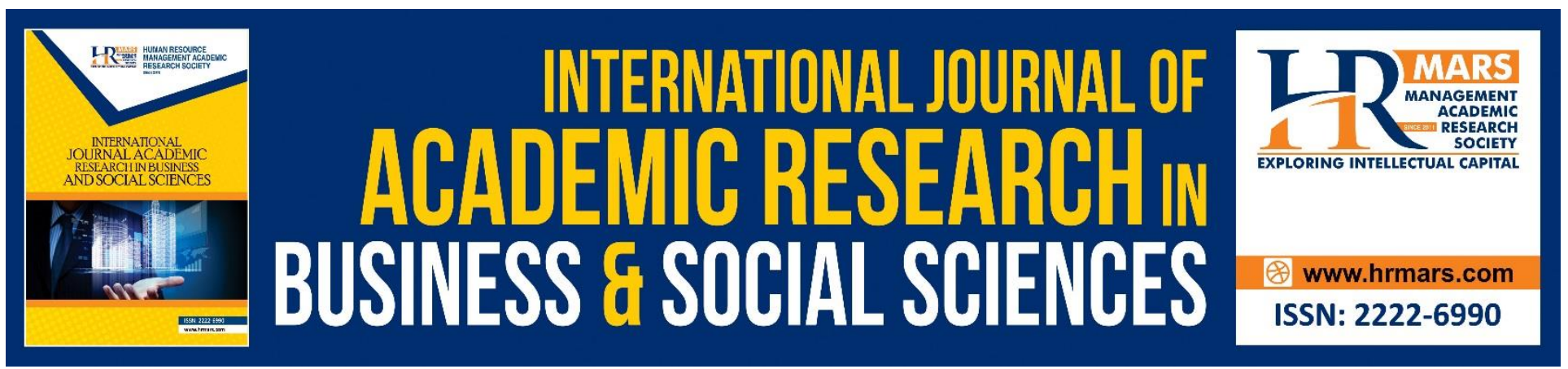

\title{
Digital Innovation: Competitive Strategy for College Startups in Nigerian Campuses
}

\author{
Jude Kenechi, Onyima \\ Nnamdi Azikiwe University, Awka Nigeria \\ Email: kcdoniel@yahoo.com \\ Purity, Ndubuisi \\ Nnamdi Azikiwe University, Awka
}

\begin{abstract}
The objective of this study was to determine the extent to which digital innovations affect Michael Porter's competitive strategies: cost leadership, differentiation management and niche maximization of college startups. Rise in campus entrepreneurship in developing economies are attributed to digital revolution and friendly environmental factors but whether uptake of digital innovation has provided significant competitive advantage for college startups with less fewer resources is yet inconclusive. Questionnaire and interview were employed to generate responses from two hundred and forty student entrepreneurs from twelve universities in Nigeria. Findings revealed that digital innovation is not just a strategy but a source of competitive advantage, energizing other strategies and contributing significantly to business performance. There is strong relationship between digital innovation uptake and business performance in the areas of cost leadership, differentiation management and niche maximization. It is therefore recommended that proficiency in digital technology should be seen as prerequisite competence for business success and that creation of enabling digital environment should be integrated into national entrepreneurship development programme.
\end{abstract}

Keywords: Digital Innovation, Competitive Strategy, Nigerian Campuses, College Startups, Entrepreneurship

\section{Introduction}

Digital innovation plays critical roles in stimulating local development, providing solutions to context-based challenges, solving socio-economic bottlenecks and in opening up myriads of opportunities for youths and women (Mcoy and Smith, 2007; Onyango et.al,2014; Bloom et.al, 2010). Apart from influencing personal and social lifestyles, digital innovation has influenced businesses and entrepreneurship. For developing economies like Nigeria, it has enabled businesses with relatively 
INTERNATIONAL JOURNAL OF ACADEMIC RESEARCH IN BUSINESS AND SOCIAL SCIENCES Vol. 8, No. 11, Nov, 2018, E-ISSN: 2222-6990 @ 2018 HRMARS

fewer resources to bypass infrastructure barriers and gained access to global customers. It has led to the emergence of micro-multinationals which MGI (2013) defined as small businesses that uses digital technologies to access customers and suppliers globally. As Mwaura (2009) observed, it provides immediate contact to customers, simplifies business operations, encourages real-time response and synchronizes business operations in most effective and efficient way. Digital innovations like mobile phones are not constrained by space and time. In the views of Akkeran and Harker (2002), uptake of digital innovation by firms leads to effective use of commerce technologies, enabling micro, small and medium enterprises (MSMEs) to come to the limelight as well as increase the viability of many niches.

Digital innovation in this context is an expansive term that covers telecommunication and information gadgets and technologies such as mobile phones, internet, computer, audio-visual systems, soft-wares and other internet enabled gadgets that enable users to access, store, transmit and manipulate information (FATE, 2015). Digital innovations also include digital enabled services like mobile money, email services, online shopping platforms, online payment platforms, different service apps, social media platforms, internet community and varieties of online interface platforms.

Entrepreneurship is arguably the most significant area where the influence of digital innovation has been felt. It has led not only to emergence of digital entrepreneurs but also provided platform for transforming existing businesses (Parker, 2007). Digital innovation has become part of the production process, product pricing, optimization of economic opportunities, inventory management, marketing communication and matching supply with demand in an unprecedented way. As Bloom et.al (2007) observed, many digital enabled-businesses can overcome many deficiencies that crippled traditional businesses provided the right set of skills, environment and infrastructures are provided. Despite that digital innovations improve productivity and economic efficiency, many businesses have not truly maximized the benefits owing to unfriendly environment. According to Kreiser et.al (2005), environmental factors are major determinant of entrepreneurial success and government in many developing economies have been developing policies that will create enabling environment especially for digital businesses to thrive.

Recent findings revealed that there is global rise in campus entrepreneurship (locoou et.al, 2005; Harrington and Kelly, 2012). The success stories of many college startups have attracted the attention of both the media and the public generating positive attitude towards students and campus entrepreneurship. Apart from the rise in entrepreneurship education, major reasons adduced for the rise in campus entrepreneurship include increased uptake of digital innovations, the peculiarity of campus environment and the level of media attention given to celebrity entrepreneurs. There is a consensus that operating a business while schooling is becoming a norm in most campuses around the world (Fatoki, 2014).

In Nigeria, entrepreneurship has become a necessity for young people owing to unemployment challenges and the surge in digital innovations. Many students are taking initiatives to start their own business perhaps due to opportunities created by digital revolution as well as enabling environment found in the campuses. As Musa, a 23year old student narrated during an interview "There is no better environment to be creative with little than on the campus. There is no digital-enabled niche market that cannot survive better on campus. University campuses are arguably the most dynamic of all environments: new faces, varied needs, varied talents, contacts and 
resources providing fertile growth for establishment of business ventures...." Young people in school are arguably the most dynamic of youth population. The social and experimental nature of university campuses contributed to improved entrepreneurial drive among students. Desire for a better future is strong among student entrepreneurs and access to digital innovations has enabled them to operate beyond traditional business boundaries (Kola-Ogunlade, 2014; Salem,2014).

College startups leverage on digital innovations to overcome numerous deficiencies. As Vilascca (2003) and OECD (2000) noted, it has made transfer of technology easier, made privileged information easily available and provided advantage to entrepreneurs that have less fixed asset. Indeed, digital innovation has enabled college startups to reduce their operating cost, serve their target niche effectively and produce unique products that meet their clients' needs. There is increasing use of digital innovation by MSMEs especially college startups to gain advantage in the market but whether such use has significantly affected their operations is largely undetermined. The extent to which digital innovation influence the Porter's three dimensions of competitive strategies: cost leadership, differentiation and focus need to be ascertained. The objective of this study therefore is to determine the influence of digital innovation on cost efficiency, differentiation management and niche maximization of college startups in Nigerian campuses.

This paper is arranged as follows: after the introduction, literature on digital innovation, campus entrepreneurship and competitive advantage. This is followed by the theoretical framework which hinge on the Michael Porter generic competitive advantage. This is followed by the methodology, presentation of data, analysis, discussion of findings and conclusion.

\section{Literature Review}

\section{Entrepreneurship and Digital innovation}

Entrepreneurship involves recognition of economic opportunity to create value as well as acting on the opportunity. Since Schumpeter, the concept of innovation has been central to understanding entrepreneurship. Rwigems and Venter (2004) sees entrepreneurship as a process of conceptualizing, organizing, launching and through innovations, nurtures a business opportunity into a successful enterprise in an environment that is complex and unstable. Harrington et.al (2009) observed that entrepreneurs convert economic resources in area of low productivity into area of higher yield using innovative measures. Innovativeness is one of the factors that distinguish traditional traders from entrepreneurs. Uptake of available innovation such as digital innovation is one of the important steps taken by entrepreneurs.

Digital innovation entails the knowledge, capabilities, techniques and gadget that are used in information and communication. It refers to as digital applications and devices that create utility. It is transforming how people work and interact, provide access to information, bypass intermediaries, gain requisite knowledge, provide opportunity for knowledge sharing, personalized alerts and easy access to technical assistance (Onyango et.al, 2014; Muraya, 2006). Digital innovation creates opportunity for entrepreneurs to work from remote areas, to work at different locations and time zone. It makes new products globally accessible by default, removing the need to acquire all fixed assets, reducing the need for big physical space. As Kumar and van Welsum (2013) noted, it eliminates the need to spending on fixed asset before earning revenue, increasing real-time response and on demand consumption thereby increasing cash flow for businesses. 
Digital innovation helps in effective utilization of capital, scaling up of operations without many hitches, respond to global demand and manage cost (Van Welsum, 2016; Bloom et. al, 2010). It lowers startup costs due to cheap access to resources and reduced operating cost. Arguably, MSMEs lack experience, market power, access to finance and networks. However, Digital innovation has enabled them to overcome these barriers. Social media and other online platform have opened up wealth of experience and access to information which hitherto was expensive to procure. It bridges the gap between formal and informal sector, bringing the youths to the centre of industrial activities because of their ability to drive the innovation. As Harrington and Kelly (2012) discovered, digital innovation has contributed to emergence of opportunity-driven entrepreneurs- people who established business because of perceived opportunity. This is against necessity-driven entrepreneurs- people who became entrepreneurs because they have no other choice.

Digital innovation has contributed significantly to changing the perception of Sub-Saharan Africa as a lost continent. Presently, the continent is experiencing commercial vibrancy in telecommunication, banking, construction and service. Many African entrepreneurs are moving away from mineral extraction to knowledge-based and technology-based sectors. Moreover, the service sector is expanding rapidly with the private sector playing a leading role. According to Harrington and Kelly (2012), rate of return on foreign investment in Sub Saharan Africa is higher than any other group of developing economies as digital innovation transforms entertainment, transportation and the retail sectors. As observed by Kola-Ogundele (2014), digital innovation has fundamentally configured the manner in which people discover and access opportunities. It has minimized the need for physical infrastructures which have been the major barriers confronting many startups. Online platforms like Konga and Jumia provide access to global markets. The influence of digital innovation on the Nigerian economy is increasing. According to it has attracted over 200 million worth of foreign direct investment as the industry. is now worth over 12 billion (FATE, 2014). Nigeria, Africa's largest internet market with over 145 million subscribers has experienced dramatic change owing to the innovation. This technology has enabled easy access to suppliers, closer relation with customers and ability to display wares without physical shops. Businesses no longer require physical presence. One can buy and sell with ease since virtual businesses are increasingly taking over the commercial space. For entrepreneurs, digital innovations provide new opportunities to reduce cost, enjoy easy payment platforms and easy tracking of activities.

\section{Campus Entrepreneurship}

Youth resource has been identified as the most valuable development factor in (Rao, 2014). In Nigeria, over 60 percent of the working population is youth and various governments in Africa are realizing the importance of youth and student entrepreneurship in the quest for development (NBS, 2014). A number of reports on African entrepreneurship recommended successful identification and implementation of youth friendly policies as a gateway to emergence of innovation-driven economies. Schroder (2005) and Chary and Libecap (2000) have also identified entrepreneurship education and training as a critical factor in cultivating entrepreneurial intention and culture. At present, all recognized higher education institutions in Nigeria offer courses in entrepreneurship. Some have entrepreneurship centers and embark on various business stimulation activities. There is 
INTERNATIONAL JOURNAL OF ACADEMIC RESEARCH IN BUSINESS AND SOCIAL SCIENCES Vol. 8, No. 11, Nov, 2018, E-ISSN: 2222-6990 @ 2018 HRMARS

also an increase in the number of students who are combining their academic studies with entrepreneurial activity or paid employment.

NBS (2014) observed that over $32 \%$ of students in Nigerian universities combine education with work and business and this increase can be attributed to several factors: the economic situation in most families where students must cater for themselves, increase in adult education enrollment, the urge among many business people to go back to school, the reality that has dawned on many people that white collar jobs have become extremely competitive due to excessive number of qualified applicants chasing fewer positions, the attractiveness of entrepreneurship lifestyle, the ease at which some skills can be learnt in school as well as digital revolution which makes entrepreneurship attractive (Donat,2014). Campus entrepreneurship covers all entrepreneurship opportunities that exist in higher educational institutions which students can identify and exploit. Successful ventures are coming out of universities steadily as many entrepreneurs convert their skills and passion into business ventures while earning their academic degrees.

College startups include all micro and small scale businesses that are established and managed by students. These school-to-business entrepreneurs have exploited opportunities in their environment and converted economic resources from regions of low yield into higher yield (Campus entrepreneurship, 2014, Fatoki, 2014; Rao, 2014). Micro, small and medium enterprises (MSMES) in campuses provides part-time job opportunities, assist well established firms, handle outsourcing, provide innovations and stimulate competition. They serve their niches effectively using cost effective and unorthodox approach in marketing, production and management. In the views of Kirkwood (2009) and Fatoki and Garve (2010), motives of starting college startups include family related motivations, need to be independent, need to be busy, need to maximize opportunities, need to create an alternative source of income, need to build capacity as well as the need to prepare for life after school. Other reasons include increased interest in social enterprises, increased influence of social networks and the need to create alternative extracurricular activities (Quality Assurance Agency,2012). Learning and experiencing enterprises while in school have several benefits: it provides alternative options especially in regions of high unemployment rate, it develops willingness and confidence to take risk. It creates discipline needed for entrepreneurs as well as creative questioning skills. Kanffman Centre of Entrepreneurship Leadership (2001) observed that participation in seminars, competitions, online networks and other business stimulation activities contributed to the rise in campus entrepreneurship.

The importance of environment in nurturing entrepreneurial intention and culture cannot be overemphasized. As Potter (2008) observed, imposing certain culture in the society can help some individuals to maximize collective social and economic success. Campus environment provides student with relatively favorable environment for entrepreneurial activities. These include public facilities and infrastructures which they could use, social networking opportunities, increased sensitivity to other people's needs, experimental nature of campus activities, favorable attitude towards failure and willingness to assume risk (Kreiser et.al, 2001). It is argued that campus environment is relatively better for entrepreneurial development owing to available training and exposure, technological readiness, favorable cultural and social norms, availability of research and development outputs, favorable government policies and infrastructures. 
INTERNATIONAL JOURNAL OF ACADEMIC RESEARCH IN BUSINESS AND SOCIAL SCIENCES Vol. 8, No. 11, Nov, 2018, E-ISSN: 2222-6990 @ 2018 HRMARS

Campus environments are different from other business environments because of the inherent prevailing attitude. Whereas in other environments, entrepreneurship is seen as a survivalist activity, in a campus environment, it is seen as an opportunistic activity. Students move into entrepreneurship as a career choice and not as what they must do if they need to survive. Necessity driven entrepreneurs are pushed into starting a business because they have no choice whereas opportunity-driven entrepreneurs start up businesses because of the opportunities they perceived thus bringing satisfaction and a sense of fulfillment. Cost structure of college startups is also different because they seem to operate in innovation-driven sectors unlike in other businesses that seem to operate in factor-driven sector.

Herrington and Kelly (2012) identified attitude as a significant factor in emergence of entrepreneurs. They also observed that young people have more positive attitude towards entrepreneurship. In campus environment, attitude to failure is mild because businesses are seen as experiments which can fail or succeed. College entrepreneurs laugh over their mistakes, discuss failures and successes openly and seek counsel. The environment is knowledge-based as against activity-based seen in other MSMEs. Campus entrepreneurship is characterized by intense differentiation and opportunity-motives unlike traditional entrepreneurship that is characterized by little differentiation, "me too' business and the need for survival.

\section{Digital Innovation as a Competitive Advantage}

Digital innovation enables creation of utility. Digital innovation is a generic name for the knowledge, capabilities, gadgets and procedures available for transforming inputs into outputs. Competitive advantage on the other hand refers to offensive and defensive actions taken by entrepreneurs to gain favorable position in the market. Many studies have established strong relationship between digital innovation and performance of organizations (Donat,2014, Chaffy,2007; Salem, 2014).It improves decision making process, increases efficiency in operations and gives a business edge over competitors. As Chaffy (2014) observed, it has emerged into a source of competitive advantage, enabling businesses to compete favorably as well as beat competition. Schroeder et.al (2005) observed earlier that linkage exist between business output and the type of technology chosen. Faezeh et.al (2014) discovered that digital innovation reduces cost, bureaucratic bottlenecks and play critical roles in generating changes in organizations. Teodoras et.al (2014) observed that a relationship exist between information and communication technologies and product sales process while Rasonlinjad et.al (2010) observed strong relationship between digital innovation and job creation. Dzokoto (2012) discovered that mobile money, one of the popular digital innovations has significant impact on money related practices of businesses in Ghana while Litaoo et.al (2011) identified that strong linkage exist between ICT, entrepreneurship speed and employment generation. As Duncumbe (2013) noted, digital innovation generates values for organizations that apply them which he called ubiquity- availability anywhere and anytime, interactivity-higher level of customer support and communication, localization-breaking barrier posed by distance, personalization-increase in customized market offering, and convenience. Indeed, digital innovation has reconfigured economic activities in an unparallel way.

Poor awareness, high cost of training, absence of ICT environment and difficulty in integrating other technologies with digital innovations have been identified as barriers against uptake of digital 
innovations by entrepreneurs in developing economies. (Glovanni and Mario, 2003; Onyango et.al,2014). However, campus environment has mitigated most of these challenges. Digital innovation is prevalent in campuses because it is relatively affordable, because of the increasing need of digital innovations in academic activities, high technological competence that exist in campuses, available ICT environment, youth culture driven by digital technology and the need to form unique identity among students. Student-entrepreneurs adopt digital innovations in order to beat time barrier as well as be on the go with trading partners. MSMEs in campuses generally lack experience, market power, access to finance and networks. However, digital innovations have created platform for them to overcome these limitations. They have made privileged information available not only to rich people but to 'sharp people". Many college startups are digital enabled, allowing them to challenge traditional businesses in terms of speed, and efficiency. Van Welson and Lanvin (2012) opined that students because they possess e-leadership skills were able communicate their businesses to important stakeholders cheaply as well as organize their resources more efficiently. Most campus entrepreneurs possess soft skills which are the skills needed to exploit physical infrastructures. They possess business acumen and pertinent skills needed to operate in a knowledge-based economy. Openness to digital innovation enables campus entrepreneurs to utilize capital effectively, scale up operations without many hitches, manage their cost effective and respond to global demand. Apart from lowering startup costs and operating cost, it provides access to networks and resources that hitherto was outside their reach.

\section{Theoretical Framework}

This study is based on the Michael Porter generic competitive strategies framework developed in 1986. A firm gains competitive advantage when it can perform chains of business activities cheaply or better than its competitors. Competitive strategy grows out of the value a firm is able to create from its buyers that exceed the cost of creating it (Tarnwa, 2013). Generic strategies help organizations to cope with the five competitive forces in the industry: bargaining power of suppliers, threat of substitute, bargaining power of buyers and threat of new entrants. According to Porter (1996), there are three generic competitive strategies: cost leadership, differentiation and focus. A firm that pursues cost leadership strategy produces standardized products and uses economies of scale, experience curve effect and a large customer base to achieve low cost; lower than the industry average. This is possible when there is tight cost control, when there is access to cheap capital, when there is close supervision of labor that lead to easy manufacturing. Differentiation strategy focuses on creating product that is unique in the industry; using brand name, design, features, customer service and network to generate advantage in the market place. Firms that pursue differentiation strategy selects one or more product attributes considered as important and positions itself to meeting the demands of the attributes. Focus strategy entails choosing a narrow competitive scope within the industry and positioning on serving the chosen segment to the exclusion of other market segment. In this strategy, energy is focused on a niche and market mix is designed to meet the needs of such narrow market segment. The focus is on effectively serving the selected market and not on efficiency. Many authors believed that it is difficult to achieve both cost leadership and differentiation at the same time. However, uptake of digital innovation seems to have 
INTERNATIONAL JOURNAL OF ACADEMIC RESEARCH IN BUSINESS AND SOCIAL SCIENCES Vol. 8, No. 11, Nov, 2018, E-ISSN: 2222-6990 (C) 2018 HRMARS

enabled college startups to gain competitive advantage in the market place in the three dimensions as seen in fig 1.

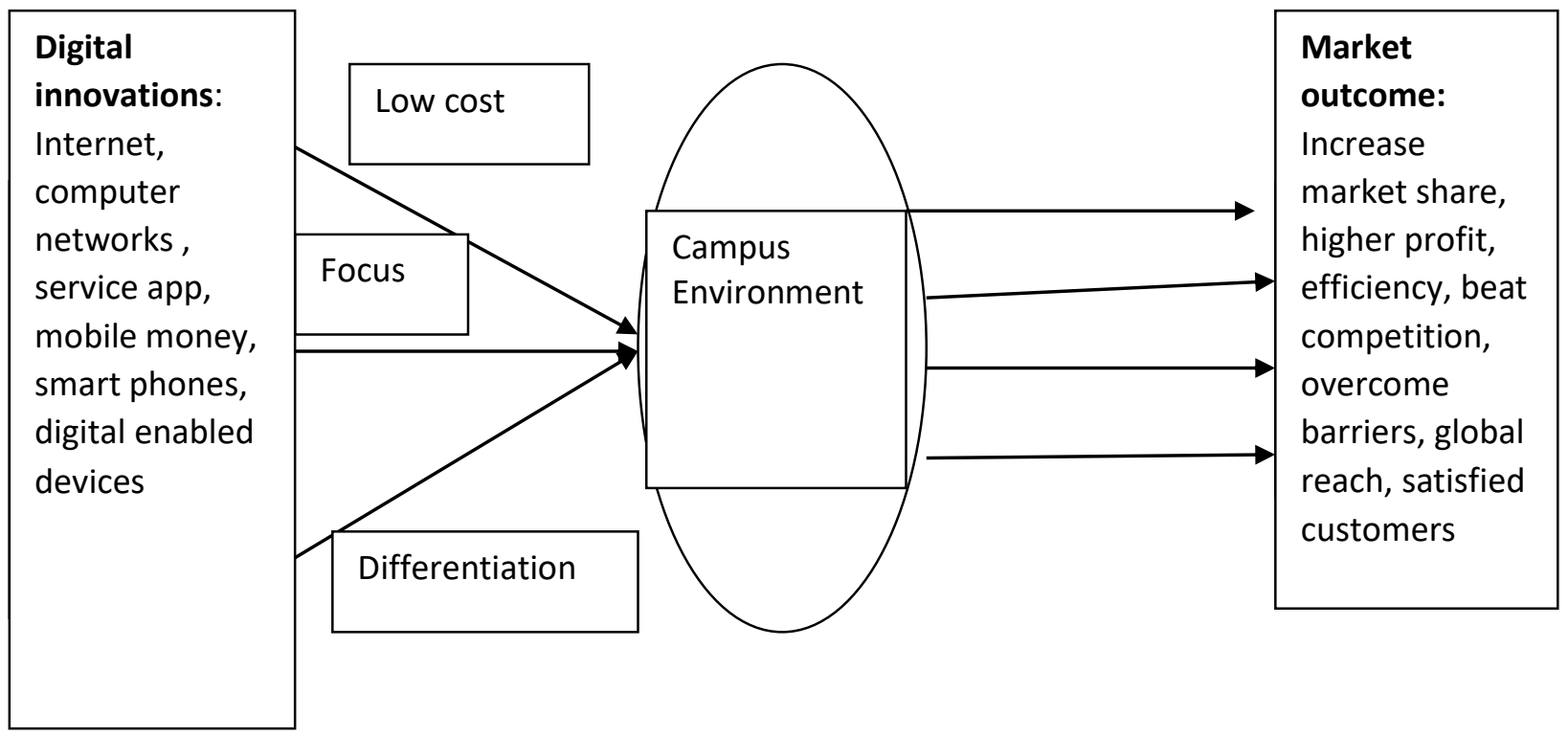

Fig.1. Framework showing how digital innovations through the dimensions of competitive advantage including environment can influence market outcomes

From this framework, the following hypotheses were developed

$\mathrm{Ho}_{1}$ : Uptake of digital innovation does not have significant relationship with cost leadership of college startups in Nigerian campuses

$\mathrm{Ho}_{2}$ : Uptake of digital innovation does not have significant relationship with differentiation management of college startups in Nigerian campuses

$\mathrm{Ho}_{3}$ : Uptake of digital innovation does not have significant relationship with niche maximization of college startups in Nigerian campuses

The argument in this study is that college startups have not significantly leveraged on digital innovations to achieve the three dimensions of competitive advantage. They are unable to device cost effective production, marketing and procurement arrangement. Digital innovations and campus environment have not enabled them to focus on particular market segment and they have not creatively entice and attract customers through strong differentiation strategies such as use of personal selling, use of friendlier platform, mix of social/emotional driven messages and aesthetic designs.

Indeed, many authors argued that digital innovations as employed by campus entrepreneurs suppose to influence low cost, differentiation and focus dimensions of competitive strategies but there is limited evidence to prove it. Furthermore, despite the relevance of Michael Porter's generic strategies towards understanding why businesses flourish; only few studies have examined digital innovation as source of competitive advantage. This study therefore examines the effects of digital 
INTERNATIONAL JOURNAL OF ACADEMIC RESEARCH IN BUSINESS AND SOCIAL SCIENCES

Vol. 8, No. 11, Nov, 2018, E-ISSN: 2222-6990 C 2018 HRMARS

innovation on cost reduction, product differentiation and niche maximization among college startups in Nigerian campuses.

\section{Method}

The study was conducted in Nigeria and two hundred and forty students from twelve universities who established and currently manage business ventures formed the sample size. Multi-stage sampling technique was adopted in the study. Firstly, two universities were randomly selected from each of the six geo-political zones in Nigeria. Secondly, snowballing technique was used to generate probable list of students in each of the universities that have established and manage business ventures. Thirdly, $25 \%$ of the names in the list from each of the 12 universities were proportionally selected using simple random sampling technique. Taro Yamani formula for determining sample size was thereafter employed thus giving a sample size of 240 students. Questionnaire was the instrument of data collection and some responses generated were supplemented with interview. Major variables used in the study were the extent of use of digital innovations, cost leadership, niche maximization and differentiation strategy. Extent of adoption of digital innovation was captured using rating scale 1-7 where 1 represents 'no use' while 7 represent very extensive use. Cost leadership was captured using return on investment (ROI) and return on assets (ROA). ROI was calculated as average net profit for past two years divided by average equity. ROA was calculated also as average net profit for the past two years divided by average total asset. Niche maximization and differentiation strategy were captured using rating scale where 1represent absence of the strategy while 7 represents full implementation. Mean rating was computed to show opinion of the respondents while correlation analysis was used to establish the nature and strength of relationship between digital innovation uptake and firms' competitive advantage. Mean score of above 3.0 was adjudged as agreement while mean score of less than 3.0 was adjudged to be disagreement with the statement made. T-test was employed to test the hypothesis at five percent level of significance. Decision rule was to accept the null hypotheses when the calculated t-statistic is less than the tabulated t-statistic. 
INTERNATIONAL JOURNAL OF ACADEMIC RESEARCH IN BUSINESS AND SOCIAL SCIENCES

Vol. 8, No. 11, Nov, 2018, E-ISSN: 2222-6990 (C) 2018 HRMARS

\section{Results and Discussion}

Table i. Mean rating on the contributions of digital innovations to the 3 dimensions of competitive strategy.

\begin{tabular}{|c|c|c|c|c|c|c|c|}
\hline Cost Leadership & SA & A & $\mathrm{N}$ & $\mathrm{D}$ & SD & $\mathrm{X}$ & Remark \\
\hline Digital innovations reduce marketing costs & 122 & 108 & 3 & 7 & 0 & 4.43 & Accept \\
\hline Digital innovations reduce procurement costs & 91 & 102 & 4 & 38 & 5 & 3.98 & Accept \\
\hline Digital innovations reduce startup costs & 71 & 150 & 2 & 14 & 3 & 4.13 & Accept \\
\hline Digital innovations reduce administrative costs & 72 & 106 & 6 & 44 & 12 & 3.76 & Accept \\
\hline Digital innovation reduces transportation cost & 69 & 123 & 4 & 25 & 19 & 3.83 & Accept \\
\hline Digital innovations reduce personnel costs & 54 & 98 & 9 & 50 & 29 & 3.41 & Accept \\
\hline \multicolumn{8}{|l|}{ Differentiation } \\
\hline $\begin{array}{l}\text { Digital innovations contribute to product differentiation: } \\
\text { ordering, installation, delivery, customer consulting. }\end{array}$ & 79 & 98 & 12 & 27 & 24 & 3.75 & Accept \\
\hline $\begin{array}{l}\text { Digital innovations contribute to channel differentiation: } \\
\text { expertise, performance, coverage }\end{array}$ & 108 & 89 & 8 & 19 & 16 & 4.06 & Accept \\
\hline $\begin{array}{l}\text { Digital innovations contribute to image differentiation: } \\
\text { symbol, media, atmosphere }\end{array}$ & 126 & 97 & 2 & 10 & 5 & 4.37 & Accept \\
\hline $\begin{array}{l}\text { Digital innovations contribute to personnel } \\
\text { differentiation: competence, courtesy, credibility, } \\
\text { responsiveness, reliability, communication }\end{array}$ & 82 & 124 & 3 & 22 & 9 & 4.03 & Accept \\
\hline $\begin{array}{l}\text { Digital innovations contribute to brand management: } \\
\text { packaging, labeling }\end{array}$ & 66 & 118 & 12 & 27 & 17 & 3.79 & Accept \\
\hline \multicolumn{8}{|l|}{ Focus (Niche maximization) } \\
\hline $\begin{array}{l}\text { Digital innovations contribute to understanding } \\
\text { customers sets of needs easily }\end{array}$ & 71 & 106 & 20 & 31 & 12 & 3.80 & Accept \\
\hline Digital innovations contribute to viability of niches & 102 & 96 & 2 & 30 & 10 & 4.04 & Accept \\
\hline Digital innovations contribute to market partitioning & 74 & 89 & 14 & 42 & 21 & 3.64 & Accept \\
\hline $\begin{array}{l}\text { Digital innovations contribute to tailoring marketing } \\
\text { needs of local customer group }\end{array}$ & 89 & 112 & 3 & 28 & 8 & 4.03 & Accept \\
\hline Digital innovations contribute to mass customization & 51 & 68 & 24 & 61 & 36 & 3.15 & Accept \\
\hline Digital innovations contribute to clustering of preferences & 64 & 78 & 17 & 52 & 29 & 3.40 & Accept \\
\hline $\begin{array}{l}\text { Digital innovations contribute to real time research and } \\
\text { insight into customers' current preferences. }\end{array}$ & 94 & 108 & 4 & 27 & 7 & 4.06 & Accept \\
\hline
\end{tabular}

Table i. revealed that digital innovations influence all the elements of competitive advantages. The mean rating is above 3.0 which is the threshold for deciding whether there is influence or not. This finding is not different from the responses generated during interview with the same respondents. ".....The change brought by digital innovations is evident in my business. Without it, I would not have been here. It is only when you come to my office that you will realize that I am not rich in terms of physical asset. Digital innovation has given us the youths avenue to run businesses with intangible asset..." (A 21 year old student who manages online payment solution venture). The perception of campus entrepreneurs with regard to the influence digital innovations on their performance justifies the assertion by some authors that digital innovation is indeed a source of competitive advantage, propelling other elements of the business and providing leverage for effective, efficient and speedy operation. Porter (1996) opined that it is difficult to achieve both the 
INTERNATIONAL JOURNAL OF ACADEMIC RESEARCH IN BUSINESS AND SOCIAL SCIENCES

Vol. 8, No. 11, Nov, 2018, E-ISSN: 2222-6990 @ 2018 HRMARS

cost leadership and differentiation dimensions at the same time. In other words, it is difficult to achieve low cost when the target is to serve differentiated product. This finding however shows that digital innovation can help businesses especially MSMEs to achieve both low cost and effective differentiation at the same time.

Table ii. Correlation between uptake of digital innovations and 3 dimensions of competitive strategy

\begin{tabular}{|l|l|l|l|}
\hline Variables & $\begin{array}{l}\text { Pearson's Correlation } \\
\text { coefficient }\end{array}$ & t-statistic & Sig. \\
\hline ROA( Cost leadership) & 0.64 & 4.890 & 0.039 \\
\hline ROI (Cost leadership) & 0.69 & 5.183 & 0.032 \\
\hline Index of Differentiation & 0.51 & 3.968 & 0.043 \\
\hline $\begin{array}{l}\text { Index of niche } \\
\text { maximization }\end{array}$ & 0.59 & 4.163 & 0.048 \\
\hline
\end{tabular}

Table 2. revealed the nature and strength of relationship between adoption of digital innovation and the three dimensions of competitive advantage. There is positive relationship between the variables suggesting that increase in adoption of digital innovation correlates with increase in competitive advantage. The degree of relationship between digital innovations and competitive advantage is strong and significant suggesting that digital innovation boost competitive advantage of the college startups studied. The calculated t-statistic for the three hypotheses is higher than the tabulated t-test and also significant at five percent level of significance. Since the calculated is more than the tabulated, the three null hypotheses were rejected. We therefore conclude as follows: There is a significant relationship between uptake of digital innovation and cost leadership, differentiation management and niche maximization of college startups in Nigerian campuses.

\section{Conclusion and Recommendations}

Digital innovation is assuming a pivotal position in business activities and its impact is overarching. Apart from providing platform for entrepreneurs with less fixed assets, it has increased efficiency of business operation, providing strong leverage for MSMEs to compete offensively in the market. Adopting digital innovations boost competitive advantage of firms in three dimensions of cost leadership, differentiation and niche maximization. Any firm that is neglecting digital innovation is weakening its competitive power and may not survive in the market place in the long run. Effective employment of digital innovation is not only a strategy; it is the energizer of all other strategies and its effect on performance of business operation is significant. Having established the critical importance of digital innovation in the lives of MSMEs, it is recommended that

- Government should as a matter of urgency integrate creation of enabling digital environment as part of national development entrepreneurship package. It is a necessity for business survival, and not a luxury.

- Regulatory agencies and governments should understand the increased interest of local and international investors in the nation's digital space and cooperate with them in harnessing the potentials in the sector. 
- $\quad$ Since entrepreneurship thrives when there is enabling environment, effort should be made by all development stakeholders to create a campus-like environment, where fear of failure is nearly inexistent, where businesses are driven by opportunities and not by absence of alternatives.

- Competence and proficiency in digital technology has become a critical skill for entrepreneurs. All would be entrepreneurs should endeavor to acquire the skill as a requirement for business success. Digital technology training centre should also be created especially in places where youths live to enable them acquire the skills that will metamorphose into business ventures tomorrow.

\section{References}

Bloom, N., Sadun. R and Reenen. J. (2007), 'Americans do I.T. better: US Multinationals and the productivity miracle,' Centre for Economic Performance, CEP Discussion Paper No.788, April.

Bloom, N.. Draca, T. Kretschmer, R. Sadun,P and Reenen. J. (2010), 'The Economic Impact of ICT,' SMART N. 2007/0020, Final Report, Center for Economic Performance, January2010, Report for the European Commission.

Campus Entrepreneurship (2014), About campus entrepreneurship [Online] Available: http://campusentrepreneurship.wordpress.com/about-edu-entrepreneurship/ (March 19, 2016)

Charney, A., and Libecap, G.D. (2000). The Impact of Entrepreneurship Education: An Evaluation of the Berger Entrepreneurship Program at the University of Arizona, 1985-1999. Report to the Kauffman Center for Entrepreneurial Leadership, Kansas City, Missouri

Donat. B. (2014) Impact of Technology on the Business Strategy Performance Relationship in Building Core Competence in Uganda's Small and Medium Enterprises. Conference Proceedings of the $7^{\text {th }}$ international Conference on Innovation and Management

Ducumbe, R. (2013). Mobile phone innovations, M-Business and SMEs in Developing Countries. WTO Workshop on e-commerce development and SMEs

FATE (2015). How ICT is influencing the rise of entrepreneurship in Nigeria. FATE Foundation Report 6.

Fatoki, O., and Garwe D. (2010). Obstacles to the growth of new SMEs in South Africa: A principal Component analysis approach. African Journal of Business Management, 4(5): 729-738.

Fatoki, O. (2014) Students Entrepreneurs in University Campus in South Africa: Motivations, Challenges and Entrepreneurship Intentions. Mediterranean Journal of Social Sciences Vol.6 (16) 
INTERNATIONAL JOURNAL OF ACADEMIC RESEARCH IN BUSINESS AND SOCIAL SCIENCES Vol. 8, No. 11, Nov, 2018, E-ISSN: 2222-6990 C 2018 HRMARS

Faezeh H, Farhad L, S.Jamal Farajallah H.(2014).The Role of ICT in Entrepreneurship Development from Experts View of Agriculture Organization of Tehran. Bulletin of Environment, Pharmacology and Life Science Vol. 4[1] 152-156

Giovanni F. \& Mario, A. (2003).Small company attitude towards ICT based solutions: some keyelements to improve it. Educational Technology \& Society, Hershey, PA: Idea Group Publishing Guthrie

Herrington, M and Kelly, D (2012) African Entrepreneurship: Sub-Saharan African Regional Report. IDRC

Herrington. M, Kew. J, and Kew. P (2009)., Global Entrepreneurship Monitor, South African Report. From<http://www.gbs.nct.ac.za/gbswebb/userfiles/gemsouthafrica 2000pdf> (October 19, 2016).

lacovou, C, Benbasat, E and Angus. L. (2005). Electronic Data Interchange and Small Organizations: Adoption and Impact of Technology. MIS Quarterly 19(4), 121-163.

Kauffman Center for Entrepreneurship Leadership (2001).The growth and advancement of Entrepreneurship in Higher Education: An environmental Scan of College Initiatives. Training Manual for Staff.

Kirkwood, J. (2009). Motivational factors in a push-pull theory of entrepreneurship. An International Journal of Gender in Management 24(5): 346-364

Kumar, K., and . van Welsum. D (2013), 'Knowledge-Based Economies and Basing Economies on Knowledge - Skills a Missing Link in GCC Countries,' Research Report RR-188-GCC,The RAND Corporation, Santa Monica, CA.

Kreiser, P. M., Marino, L., and Weaver, K. M. (2001). "Correlates of Entrepreneurship: The Impact of National Culture on Risk-Taking and Pro-activeness in SMEs". University of Alabama, Department of Management and Marketing.

McCoy, J. and Smith, G. (2007). Mobile end-user service adoption studies: A selective Review. Scandinavian Journal of Information Systems, 14, 301-358

Muraya, P. (2006). Urban Planning and Small-Scale Enterprises in Nairobi, Kenya. Habitat International, Vol. 30 (1)127- 143

[

Mwaura, P. W. (2009). Networks, Information and Small Enterprises: New Technologies and the Ambiguity of Entrepreneurs, Information Technology for Development, Vol. 10(4) 221 - 232.

NBS(2014) Statistical Bulletin. National Bureau of Statistics Report, Abuja OECD (2012), The OECD Internet Economy Outlook 2012, OECD, Paris. 
INTERNATIONAL JOURNAL OF ACADEMIC RESEARCH IN BUSINESS AND SOCIAL SCIENCES Vol. 8, No. 11, Nov, 2018, E-ISSN: 2222-6990 C 2018 HRMARS

Onyango A, Ongus. R, Awuor. F and Nyamboga.C (2014) Impact of adoption and use of mobile phone technologies on the performance of micro, small and medium enterprises in Kishii Municipality Kenya. World Journal of Computer Application and Technology Vol.2 (2)

Parker, O. (2007). Exploring the Usage and Impact of "Transformational" Mobile Financial Services: The Case of M-PESA in Kenya. Journal of Eastern African Studies, Vol.3, (3) 509-525.

Porter, M. (1996) "What is strategy?" Harvard Business Review Vol.7 (6) :61

Tarnwar. L. (2013) Porter's Generic Competitive Strategies. Journal of Business and Management Vol. 15 (1).

Quality Assurance Agency (2012) Enterprise and Entrepreneurship Education: Guidance for UK higher education providers. www.qaa.ac.uk

Rao, D. (2014), Should Universities Become Entrepreneurial Campuses? [Online] Availablehttp://www.forbes.com/sites/dileeprao/2013/11/18/should-universities-become-

entrepreneurial-campuses/\#./?\&_suid=1399281862602030538910424623633(Feb 15, 2017)

Rwigema, H., \& Venter, R. (2004). Advanced entrepreneurship.Cape Town: Oxford University PressSouthern Africa.

Theodoros, A., Illias, P. and Panagiotis, K. (2008). ICT Impacts on Greek Entrepreneurship Accordingly to Governmental Programme.Competitive paper for Haicta Conference, 3(1): 76-89.

Salem, M. (2014) Building an Entrepreneurial Economy: Evidence from Developing Countries. International Business and Economic Research Journal Vol.13 (3)

Schröder, E. (2005). "Berufliche Selbständigkeit als Ziel? Entwicklung und Evaluation eines "Life Skills" - basierten Trainingsprograms für Jugendliche. Dissertation, Friedrich Schiller Universität Jena, Jena.

Van Akkeren, J., \& Harker, D. (2002). Mobile data technologies and SME adoption and diffusion: An empirical study on barriers and facilitators. Australasian Journal of Information Systems, 9(2), 1-16.

Van Welsum, D. (2016) Enabling Digital Entrepreneurs. World Development Report, World Bank

Van Welsum, D., and Lanvin, B. (2012), e-Leadership Skills - Vision Report, Prepared for theEuropean Commission, DG Enterprise and Industry.http://eskills-vision.eu/results-downloads/

Vilaseca, J. (2003). Las TIC y las transformaciones de la empresa catalana, Barcelona: Foundation for the Open University of Catalonia 